\title{
Comparison of Heavily Fertilized Pangola and Star Grass Pastures in Terms of Beef Production and Carrying Capacity in the Humid Mountain Region of Puerto Rico ${ }^{1,2}$
}

\author{
Rubén Caro-Costas, Fernando Abruña, and José Vicente-Chandler ${ }^{3}$
}

\section{INTRODUCTION}

Star grass (Cynodon dactylon) is extensively used for pasturage in Africa and in Asia, but little experimental information is available on its performance under heavy fertilization and intensive grazing management. In Puerto Rico, Caro, Abruña, and Figarella (4) have developed detailed research data on the response of Star grass harvested by cutting to $\mathrm{N}$ fertilization, harvest interval, and cutting height under conditions typical of the humid mountain region. Although considerable information is available on the productivity of intensively managed pastures of Guinea, Pangola, Napier, Para, and molasses grasses in Puerto Rico $(5,6)$, no experimental data has been developed concerning the performance of Star grass pastures under these conditions.

Chemical analyses have shown that young Star grass occasionally has a rather high hydrocyanic acid (prussic acid) content. There is no evidence, however, of cattle poisoning by it. Caro (3), in Puerto Rico, conducted studies to determine if this grass is poisonous to cattle. Heifers receiving no feed for the previous 36 hours were grazed on a field of heavily fertilized Star grass at 15-day intervals when the grass had a rather high hydrocyanic acid content. The cattle repeatedly consumed large quantities of Star grass relatively high in hydrocyanic acid content over a short period of time with no ill effects.

The purpose of the present study was, to compare the productivity of intensively managed Pangola and Star grass pastures on steep slopes under conditions typical of the humid mountain region of Puerto Rico in terms of carrying capacity and beef production.

1 Manuscript submitted to Editorial Board August 1971.

This paper covers investigations conducted cooperatively between the Soil and Water Conservation Research Division, Agricultural Research Service, USDA, and the Agricultural Experiment Station, Mayagüez Campus, University of Puerto Rico, Rio Piedras, P.R.

Agronomist, cooperative between the Soil and Water Conservation Research Division, ARS, USDA, and the Agricultural Experiment Station, Mayaguez Campus, University of Puerto Rico; and Soil Scientist and Project-Leader-Soil Scientist, Soil and Water Conservation Research Division, ARS, USDA, respectively. 


\section{MATEIRIAL AND METHODS}

The experiment was conducted over a period of 2 years near Orocovis, at an clevation of about 2,000 fect, with a mean annual temperature of about $75^{\circ} \mathrm{F}$. and a scasonal variation of less than $10^{\circ} \mathrm{F}$. The soil is Cialitos clay (UlTisol) with an average slope of 30 pereent and a northeast exposure. A randomized block design was employed, with treatments replicated 3 times. Individual pastures, 1-acre in size, were provided with water and salt. The soil was limed to about pH 6.0 and 1 ton of 14-4-10 fertilizer applied per acre yearly to all pastures in four equal applications at 3-month intervals.

The pastures were grazed by young Holstein heifers initially woighing about 350 pounds and replaced yearly. A different group of animals were grazed on the pastures of each grass species. The heifers were treated periodically for parasites and received no feed other than that obtained from the pastures. Two "tester" heifers were kept per acre throughout the year and additional animals added as required to consume excess forage, using the well-known "take-and-put" system. Pastures were grazed in rotation with 7 days of grazing followed by 14 days of rest.

The heifers were weighed each time they were moved from one pasture to another. A record was kept of the grazing days and gains in weight for cach animal and each pasture. The total digestible nutrients produced by each pasture were calculated from these data following recommendations of the Pasture Research Committec (1). Carrying capacity was calculated from these data and expressed in terms of 600-pound steers.

During the sccond year of experimentation, $S$ areas in each pasture, each 1 yard square, were cut before and after each grazing and the forage from these weighed. From these data the amount of forage actually consumed by the cattle was determined by "difference". The areas cut in each grazing round were different to ,reflect trampling and grazing effects.

Before each grazing, 10 forage samples were taken in each pasture by plucking to simulate grazing. These samples, presumably typical of the forage consumed by the grazmg cattle, were analyzed to determine their crude protein content.

\section{RESULTS AND DISCUSSION}

Table 1 shows that Star grass produced more beef per acre and that cattlo grazing this grass made higher average daily gains per head than those on Pangolit grass. On the average, Star grass (figure 1) produced 1,350 pounds gain in wojght per acre yearly with average daily gains per head of 1.33 pounds as compared to 947 pounds gain in weight and daily gains of 1.09 pounds on P'angoli grass.

This table also shows that Star grass produced an average of 9,260 
Tand: 1.-Comparative produclivily of inlensively managed Slar and Pangola grass pashures in lerms of beef production and carrying rapacily over 2 conseculive years of grazing at Orocovis, P.R.

\begin{tabular}{lcccc}
\hline Grass & $\begin{array}{c}\text { Gains in } \\
\text { weight ner } \\
\text { acre yearly }\end{array}$ & $\begin{array}{c}\text { Average } \\
\text { daily gans } \\
\text { per head }\end{array}$ & $\begin{array}{c}\text { Total digestible } \\
\text { nutrients per } \\
\text { acre yearly }\end{array}$ & $\begin{array}{c}\text { Carrying } \\
\text { capacity in } \\
\text { terms of 600- } \\
\text { pound steers }\end{array}$ \\
\hline Star & Pounds & Pounds & Pounds & Number \\
Pangola & 1,350 & 1.33 & 9,260 & 3.00 \\
L.S.D.05 & 047 & 1.09 & 8,030 & 2.50 \\
\hline
\end{tabular}

${ }^{1}$ One 600-pound steer $=8.5$ pounds total digestible nutrients daily.

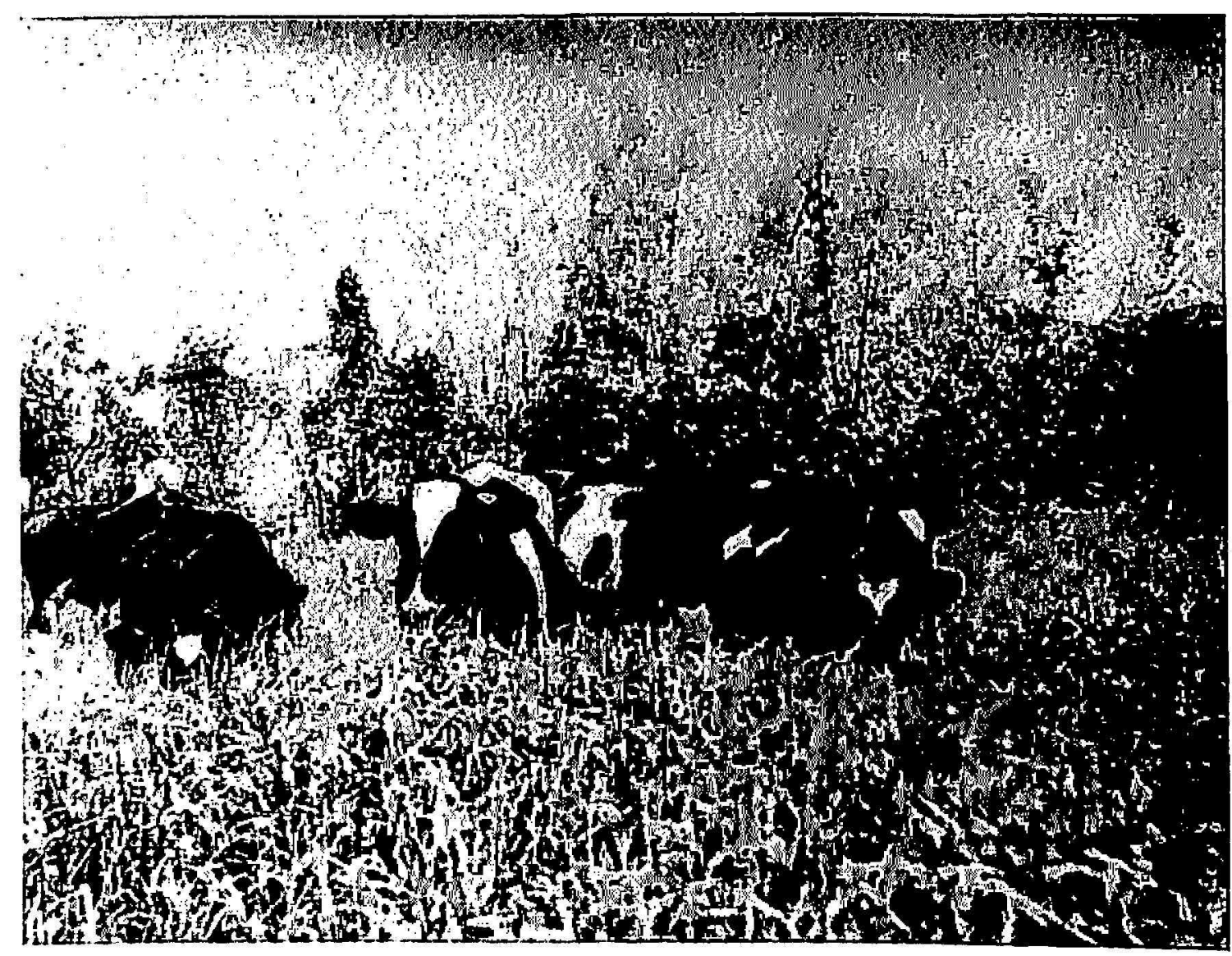

Fic. 1.-Cattle grazing well fertilized Stur grass pastures under conditions typical of the humid mountain region of Puerto Rico. These pastures ontyielded those of similarly treated Pangola grass pastures, carrying the equivalent of three 600 -pound steers per acre and producing 1,350 pounds of grain in weight per acre yearly with average daily gains of 1.33 pounds per head.

pounds of total digestible nutrients and had a carrying (alpacity cepuivalent to three 600-pound steers per acre compound to 8,030 pounds of total digestible nutrients and a carrying capacity of 2.5 stecrs per acre on l'angola grass. 
Star grass produced an average of 17,167 pounds of dry forage consumed by the cattle per acre yearly during the second year of grazing (2,000 pounds more than Pangola grass). Calculations based on these dry forage yields and the calculated total digestible nutrients consumed by the cattle during this year indicate that Star and Pangola grasses had an apparent digestibility of about 55 percent.

Annual rainfall was 75.6 inches during the first year of experimentation; 100.4 inches during the second year. Rainfall distribution during the experiment is shown in figure 2.

Figure 2 shows that monthly beef production for the two grasses followed a similar pattern, with Star grass generally superior throughout the year.

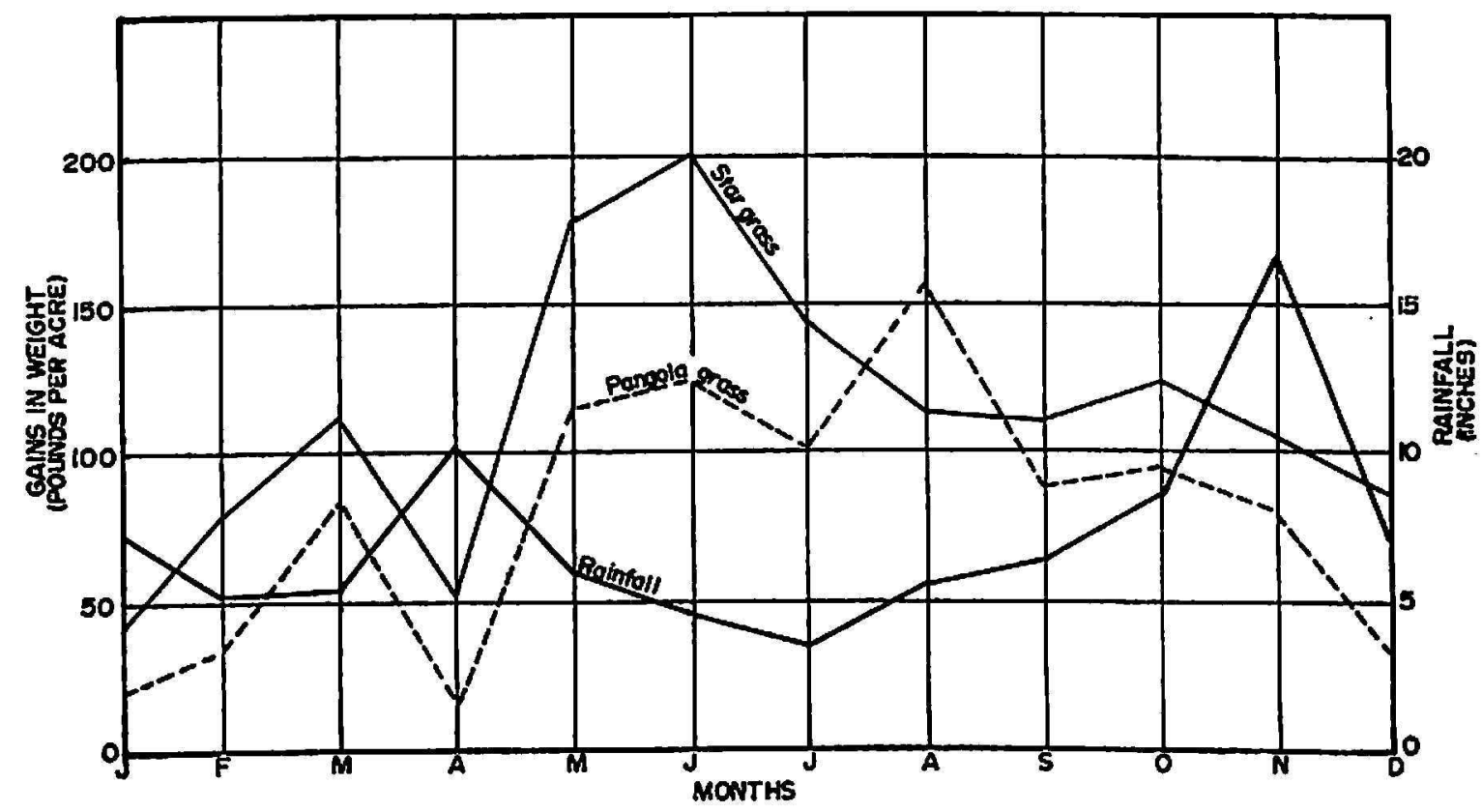

FrG. 2.-Average monthly gains in weight of cattle grazing intensively managed Star and Pangola grass pastures over a 2-year period at Orocovis, P.R.

Pangola grass flowers profusely during June followed by a flush of growth as shown in this figure.

Yields of both grasses were highest from May to October and lowest during the cooler, shorter, winter days. Excessive rainfall apparently depressed beef production.

Figure 3 shows that Star grass had a higher crude protein and dry matter content than Pangola grass throughout the second year of grazing. The dry matter content of both grasses varied considerably during the year and crude protein content ranged from a low of $\mathbf{1 1 . 3}$ percent to a high of $\mathbf{1 9 . 6}$ percent. Protein content usually was highest during the winter season of slow growth, probably as a result of the concentrating effect of lower yields in the presence of an approximately uniform level of nitrogen fertilization. 
The high dry matter yields and higher crude protein and dry matter content of Star grass throughout the year account for its superiority over Pangola grass. Star grass apparently is not susceptible to stunt disease, which affects Pangola, and is resistant to the sugarcane aphid, a major pest of Pangola.

\section{SUMMARY}

Intensively managed Star and Pangola grass pastures fertilized with one ton of 14-4-10 per acre yearly were compared in terms of beef production and carrying capacity during a 2-year period in the humid mountain region of Puerto Rico.

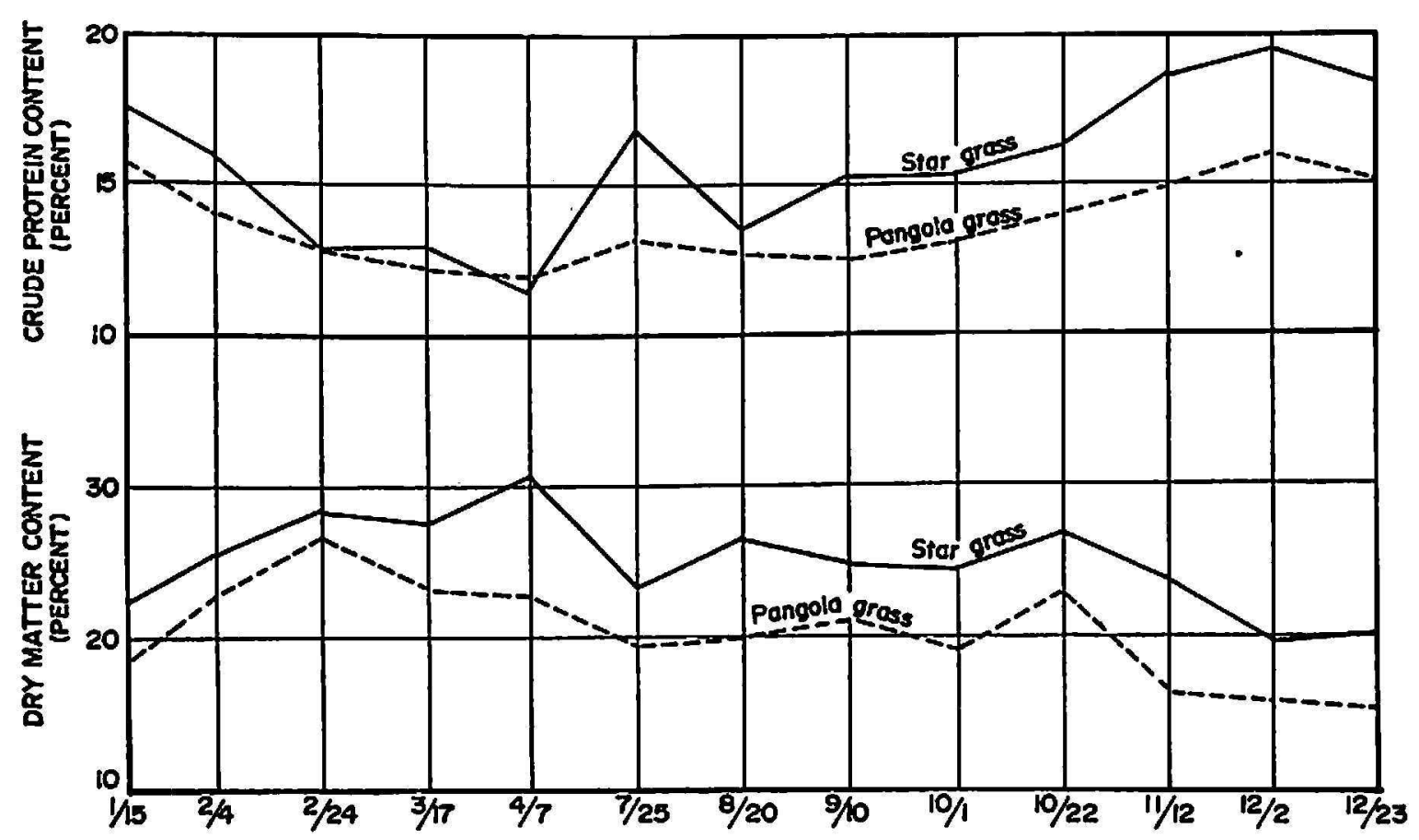

FrG. 3.-Protein and dry matter contents of Star and Pangola grasses as affected by season of the year. (All values are weighted averages.)

Star grass produced an average of 1,350 pounds of beef per acre yearly with average daily gains of 1.33 pounds per head, compared to 947 pounds of beef per acre and average daily gains of 1.09 per head for Pangola. Star grass pastures had a carrying capacity equivalent to three 600 -pound steers per acre compared to 2.5 for Pangola.

Star grass had higher protein and dry matter contents than Pangola throughout the year. Protein content of the forage ranged from 11.3 to 19.6 percent, with highest values occurring during the slow growth of winter months.

Both grasses produced lowest yields during the winter months in spite of rainfall in excess of 5 inches monthly during this period. Shorter days and 
cooler temperatures seem to be primary factors responsible for lower beef production during this season, although these variations are small in this tropical area. Excessive rainfall tended to depress weight gains.

\section{RESUMEN}

Se compararon las yerbas Estrella y Pangola en un experimento de pastoreo que se llevó a cabo por 2 años consecutivos bajo condiciones típicas de la región montañosa de Puerto Rico. Ambas yerbas se manejaron intensivamente, abonándose con 1 tonelada de fertilizante de la fórmula 14-4-10 por acre al año en cuatro aplicaciones iguales.

La yerba Estrella produjo un mayor aumento en el peso de los animales (1,350 vs. 947 libras por acre al año), una ganancia mayor en peso diario (1.33 vs. 1.09 libras por cabeza) así como una capacidad de pastoreo mayor (3.0 vs. 1.5 novillos de 600 libras por acre).

Durante todo el año la yerba Estrella demostró tener. un contenido más alto de materia seca y de proteína que la Pangola.

La época del año tuvo un marcado efecto en la productividad de los pastos y en su contenido de proteína, que varió de 11.3 a 19.6 por ciento. Durante el invierno la producción de forraje fue menor pero su contenido de proteína fue mayor.

\section{LITERATURE CITED}

1. Anonymous, Report on pasture investigation techniques, Joint Committee of American Dairy Society, Society of Agronomy, American Dairy Science Association and American Society of Animal Production, J. Dairy Sci., 26: 353-69, 1943.

2. Burroughs, W., Nutrient requirements of domestic animals, No. IV. Nutrient requirements of beef cattle, National Academy of Sciences, Nat. Res. Counc. Washington, D.C., 1963.

3. Caro-Costas, R., Star-A promising new grass for the humid region of Puerto Rico, Research Note No. 57, SWC, ARS, USDA cooperative with AES, UPR, August 1968.

4. Caro-Costas, R., Abruña, F., and Figarella, J., Effects of nitrogen rates, harvest interval and cutting heights on yield and composition of Star grass in Puerto Rico, J. Agr. Univ. P.R. (In Press).

5. Caro-Costas, R., and Vicente-Chandler, J., Effect of fertilization on carrying capacity and beef produced by Napier grass pastures, Agron. J. 53: 204-5, 1961.

6. Caro-Costas, R., Vincente-Chandler, J., and Figarella, J., Productivity of intensively managed pastures of 5 grasses on steep slopes in the humid mountain region of Puerto Rico, J. Agr., Univ. P.R., 49 (1): 99-111, 1965. 